\title{
RESEARCH ARTICLE \\ Geological Characteristics and Working Suggestions of Shuiquan Ben- tonite Mine in Chaoyang County
}

\author{
Tongyu Wang \\ Liaoning Nonferrous Geology Team 109 Co., LTD., Beijing, 122000, China
}

\begin{abstract}
The shuiquan bentonite mining area in chaoyang county, liaoning province is located in the northern margin of the north China block - yanshan middle neoproterozoic rifting belt - western liaoning Mesozoic upper superimposed basin belt - chaoyang Mesozoic superimposed basin-ling system nejinling si-yangshan volcanic rock basin. The bentonite ore bodies occur in the rhytitic breccia tuff of the lanqi formation and are stratified deposits. Based on the study of the known ore bodies, this paper summarizes the prospecting marks, summarizes the prospecting direction, and lays a foundation for the next exploration.
\end{abstract}

Keywords: Bentonite; Geological features; Advice

Citation: Tongyu Wang. 2018. Geological Characteristics and Working Suggestions of Shuiquan Bentonite Mine in Chaoyang County. International Journal of Geology, 3(1): 12-14. http://doi.org/10.26789/IJG.2018.01.003

Copyright: Geological Characteristics and Working Suggestions of Shuiquan Bentonite Mine in Chaoyang County (C) 2018 Tongyu Wang. This is an Open Access article published by Urban Development Scientific Publishing Company. It is distributed under the terms of the Creative Commons Attribution-Noncommercial 4.0 International License, permitting all non-commercial use, distribution, and reproduction in any medium, provided the original work is properly cited and acknowledged.

\section{The Background of Regional Geological}

Shuiquan bentonite mining area is located in North China block-Yanshan Middle-Neoproterozoic rift zone-Mesozoic superimposed basin belt in western Liaoning-Chaoyang Mesozoic superimposed basin-Jinlingsi in Ling system-northern edge of yangshan volcanic basin ${ }^{[1]}$. During the Mesozoic era, in the south of Chengde-Beipiao fault, the crustal activity was frequent and greatly decreased, and a Mesozoic faulted basin was formed, which deposited Mesozoic strata with great thickness and was accompanied by a large number of frequent volcanic eruptions. The Jinlingsi-yangshan fault basin has received sedimentation since Jurassic, forming a set of volcanic rocks and pyroclastic rocks with great thickness, which are mainly composed of medium-acid volcanic tuff, andesite and pyroclastic rocks, mixed with terrigenous clastic rocks and lacustrine sediments, and forming a bentonite metallogenic belt extending from Gushanzi-Xiyingzi-Shengli-Liujiazi, Chaoyang County, with a length of nearly 100 kilometers, and a large number of bentonite deposits are distributed in this metallogenic belt.

Geology of mining area.

The exposed strata in the mining area are Lanqi Formation and Tuchengzi Formation of Middle and Upper Jurassic, Yixian Formation of Lower Cretaceous and Quaternary ${ }^{[2]}$ (Figure 1).

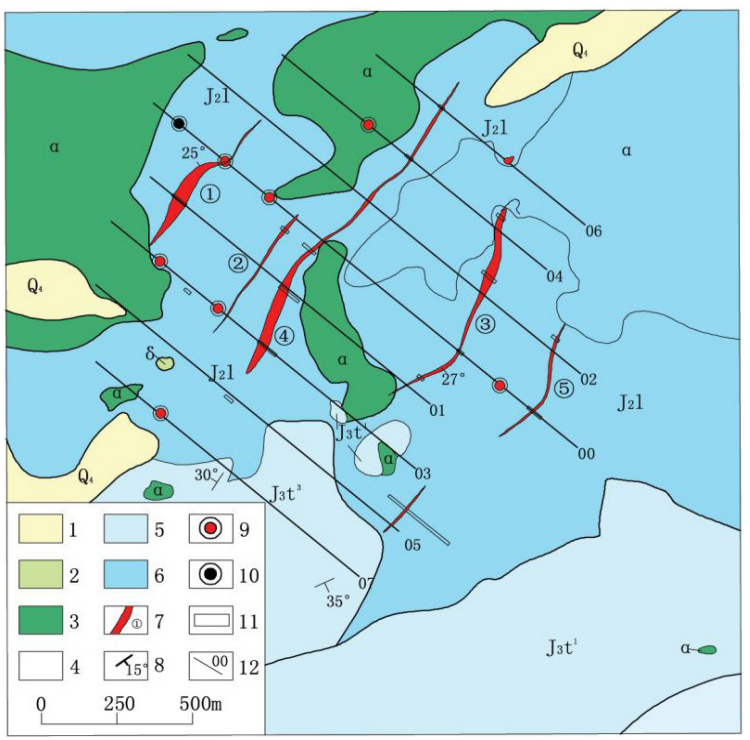

Figure 1. Geological surface of Shuiquan bentonite mining area in Gushanzi Township, Chaoyang County, Liaoning Province

1- The fourth system; 2- diorite; 3- Andesite; 4- tuff; 5- Grey purple tuffaceous sand shale; 6-rhyolitic breccia tuff; 7- Ore body; 8-Stratigraphic occurrence; 9- Drilling for ore; 10- No ore drilling; 11-exploratory trench; 12- exploration line and number.

Jurassic Lanqi Formation: rhyolitic breccia tuff, exposed in the north and south of the mining area, occurs 
in monoclinic layers, and is in contact with the overlying strata (J 3). Formation attitude, dip 130, dip $17 \sim 35$. Gray-green $\sim$ gray-white, with sandy structure, layered structure and rhyolitic structure. The rock is mainly composed of feldspar, Shi Ying, pyroclastic, vitrinite, crystal chips, etc. A small amount of breccia is found in the rock, which is composed of rhyolitic cuttings and is sub-angular. Rocks are characterized by chloritization, kaolinization and montmorillonite.

The first member of Tuchengzi Formation of Jurassic: grey purple tuffaceous sand shale, distributed in the middle and south of the mining area. It occurs in a single inclined layer, with a stratigraphic attitude of 130 and an inclination of $25 \sim 35$. It is in parallel unconformity contact with the third member of the overlying formation locally, and the sand shale is purplish red with sandy structure, layered structure and foliation. The rock is mainly composed of volcanic debris, which is sub-angular, and the cement is volcanic tuffaceous, with rare mineral crystal debris such as Shi Ying, feldspar and biotite. Shale is foliated by tuffaceous and andesitic rocks, with a single layer thickness of $1 \sim 5 \mathrm{~cm}$, with obvious shale structure foliated structure, and the tuffaceous rocks have clay mineralization and alteration phenomena such as montmorillonite.

The second member of Tuchengzi Formation, Jurassic: gray-purple breccia, distributed in the south-central part of the mining area, occurs in synclinal layers with a dip of 310 and a dip angle of $25 \sim 27$, which is in integrated contact with the third member of the overlying formation and the first member of the underlying formation; Conglomerate is grayish purple, gravels are mainly rhyolite and andesite, round and pebble-shaped, cemented by finely divided volcanic debris, and gravels are arranged in a directional way, forming rock bedding, with a layer thickness of $0.1 \sim$ $0.5 \mathrm{~m}$.

The third member of Tuzi Formation: gray-white, grayish-green tuff, which is exposed in the midwest of the mining area. Synclinically layered, stratum attitude, dip 135 and 305, dip $35 \sim 40$. Coalescent structure, locally sandy structure, block structure, mainly composed of volcanic debris and tuffaceous. The volcanic debris is subangular with particle size of $0.5 \sim 5 \mathrm{~mm}$, and the cement is tuffaceous, partially clayey and carbonated, with mineral crystal debris such as Shi Ying, feldspar and biotite.

Yixian Formation of Cretaceous System: It is mainly gray-purple andesite with andesite structure, porphyritic structure and massive structure, with few pores. The main mineral components are plagioclase, hornblende, pyroxene and a small amount of biotite. The phenocrysts are mainly plagioclase, and the matrix is cryptocrystalline, mainly felsic minerals. Many rocks have kaolinization and chloritization alteration.

Quaternary: riverbed gravel and loess, distributed in intermountain valleys and Pingchuan zone.

There are only NE-trending fold structures in the area, which are distributed throughout the mining area, showing a group of fold combinations. The north is an anticline structure, and the rock stratum inclines to the northwest, with a gentle dip angle. The south part is a syncline structure, with strata dip at 310 and 130 and dip at $25 \sim 35$. The geological structure of the whole mining area is relatively simple.

The intrusive rocks in the mining area are subvolcanic intrusions. Yanshanian diorite intruded into rhyolitic breccia tuff in Lanqi Formation in the form of rock beads, with an exposed area of about $0.1 \mathrm{~km}^{2}$.

\section{Deposit Geology}

\subsection{Geological Characteristics of Ore Bodies}

The bentonite ore body in the mining area occurs in rhyolitic breccia tuff of Lanqi Formation, which belongs to stratabound deposit. The ore body strikes to the northeast, and tends to be distributed in two groups of occurrences of northwest and southeast. The continuity of the main ore body is good ${ }^{[2]}$ (Figure 2).

(1) The first group of ore bodies: the surface engineering control is extended by $400 \sim 1200 \mathrm{~m}$, with an inclination of 310 and an inclination of $17 \sim 25$. The montmorillonite grade is $50.0 \sim 56.15 \%$, with an average grade of $53.10 \%$. The maximum vertical thickness is $21.90 \mathrm{~m}$, the minimum is $1.84 \mathrm{~m}$, the average vertical thickness is $8.99 \sim 11.99 \mathrm{~m}$, and the occurrence elevation is +33 .

(2) The second group of ore bodies: the surface engineering control extends by $430 \sim 780 \mathrm{~m}$, inclines by 130 , and inclines by $25 \sim 27$. The montmorillonite grade is $50.00 \sim 74.67 \%$, with an average grade of $55.73 \%$. The vertical thickness of the ore bodies is $23.90 \mathrm{~m}$ at maximum and $3.06 \mathrm{~m}$ at minimum, with an average thickness of $3.06 \sim 12.87 \mathrm{~m}$, and the occurrence elevation is +33 .

\subsection{Ore Quality}

The bentonite in the mining area is calcium-based bentonite, which is mainly green, followed by white and pink. They are all scales and crystals, with earthy and dense block structure. They all have soap-like or wax-like luster, obvious conchoidal fracture, smooth hand feeling, and are easy to disperse, disintegrate and swell when exposed to water.

The main mineral of the ore is montmorillonite, which contains a small amount of volcanic debris and is uneven- 
ly distributed, while feldspar, Shi Ying, biotite and other mineral debris are rare. The content of calcium-based bentonite montmorillonite (single project statistics) is $50.00 \sim$ $74.67 \%$.

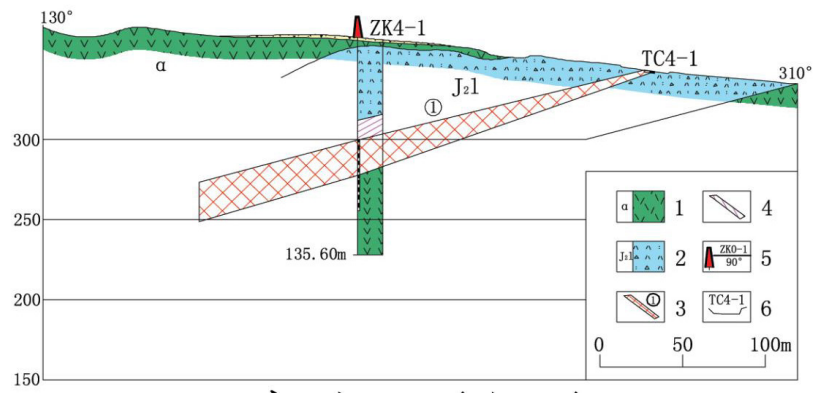

Figure 2. Geological profile of Line 4 of Shuiquan Bentonite Mining Area in Gushanzi Township.

1 - andesite; 2 - rhyolitic breccia tuff; 3 . Ore bodies; 4Mineralized bodies; 5- Drilling and numbering; 6- Trough detection and numbering.

\section{Deposit Genesis and Prospecting Criteria}

\subsection{Genesis of Deposit}

According to the characteristics of ore-bearing rocks and ore bodies in bentonite ore bodies, such as morphology, occurrence, structure, structure and ore-controlling conditions, it is preliminarily considered that the ore-forming protolith of bentonite ore is rhyolitic breccia tuff, and this tuffaceous debris forms bentonite ore through deposition, structure and thermal metamorphism and montmorillonite alteration in the later stage of subvolcanic intrusion. The genetic type of the deposit is preliminarily determined as volcanic eruption-sedimentation and metamorphism.

\subsection{Prospecting Signs}

(1) Bentonite ore body is controlled by rhyolitic breccia tuff, and its genesis is closely related to subvolcanic rock body. It is considered that the contact zone between andesite and tuff is a favorable place for prospecting.

(2)The outcrops of bentonite ore bodies on the surface belong to direct prospecting indicators.

\section{Conclusions}

A medium-sized bentonite ore has been found in this area, and the metallogenic conditions are superior, which has the conditions for forming large and super-large bentonite ore. It is suggested to further intensify prospecting for it.

After drilling verification, it is found that the eastern deep part of No.1 bentonite ore body in this area has a tendency of thickening, while the western end and deep part of No.3 ore body are not controlled. It is suggested that the next drilling construction should properly carry out the deep control to the east of Line 4 and Line 6 of No.1 ore body and the western end and deep part of No.3 ore body.

\section{References}

[1] Liaoning Geological Exploration Institute. Regional Geology of China-Liaoning Records [M]. Beijing: Geological Publishing House, August 2017.

[2] Zhang Lei, Tong Yu, Luo Jian, Li Guomin. Geological Report of General Survey of Shuiquan Bentonite Mine in Gushanzi Township, Chaoyang County, Liaoning Province [R].2013:10-35. 